\title{
Separation of Tryptophan from an Unidentified Compound (X 1) Produced from Indolepyruvic Acid by High-performance Liquid Chromatography
}

\author{
Nazimuddin MOHAMMED*, Ryoji ONODERA, \\ Munetaka MIZOKAMI and Rokibul Islam KHAN
}

Faculty of Agriculture, Miyazaki University, Miyazaki-shi 889-2192

(Received May 27, 1998)

\begin{abstract}
Indole-3-pyruvic acid (IPA) is an unstable compound and some unidentified compounds ( $\mathrm{X} 1 \sim \mathrm{X} 4$ ) were naturally produced from IPA immediately after dissolving in $25 \%$ ethanol or after incubation in MB9 buffer solution at $39^{\circ} \mathrm{C}$. Unfortunately, one of the unidentified compounds (X 1) overlapped with the peak of tryptophan (Trp), when analyzed by the previously reported method for analysis of Trp and its related compounds by high-performance liquid chromatography (HPLC). In the present study, a rapid method for the separation of Trp from X 1 was established using HPLC. LiChrospher $100 \mathrm{RP}-18$ column and methanol-50 $\mathrm{mM}$ sodium acetate buffer $(\mathrm{pH} 4.2)(20: 80, \mathrm{v} / \mathrm{v})$ as a mobile phase for isocratic elution were used for the analysis. The compounds were monitored at $280 \mathrm{~nm}$ with a UV absorbance detector. When a 5 $\mu l$ portion of deproteinized and filtered mixed sample of Trp and IPA was injected onto the HPLC system, the peaks of $\operatorname{Trp}$ and $\mathrm{X} 1$ were separated within $7 \mathrm{~min}$. The recovery of Trp was more than $96 \%$ and the minimum detectable limit was 40 pmol.
\end{abstract}

Anim. Sci. Technol. 69 (12) : 1102-1105, 1998

Key words : Tryptophan determination, Lability of indolepyruvate. Unknown compounds from indolepyruvate

Indole-3-pyruvic acid (IPA) is one of the precursors of tryptophan ( $\operatorname{Trp}$ ) biosynthesis. It is transaminated to form Trp by an enzyme, tryptophan transaminase (EC 2.6.1.27), where glutamate is amino group donor to IPA and it is in itself converted to 2-oxoglutarate. In Trp biosynthesis from IAA by ruminal bacteria, IAA has been observed to be reductively carboxylated to form IPA and then trans- aminated to form $\operatorname{Trp}^{1-3)}$. We have found that IPA was an unstable compound and it was naturally and rapidly converted to some unidentified compounds (X1 X 4 , unpublished data) even after dissolving in $25 \%$ ethanol and after incubation in MB9 buffer solution at $39^{\circ} \mathrm{C}$, which has been used for incubation of rumen protozoa ${ }^{6)}$. As far as we know, there have been no reports on HPLC methods for the

インドールピルビン酸から生成される末同定化合物（X1) とトリプトファンの高速液体クロマトグラフィーによ る分離 :ナジムディン モハマド・小野寺良次・溝上宗尚・カーンロキブル イスラム（宮崎大学農学部, 宮崎市 899-2192) 


\section{Separation of Tryptophan from Unidentified Compound}

determination of IPA.

Recently an HPLC method for the analysis of Trp and its ten related compounds has been established $^{5)}$. With this method ${ }^{57}$, however, the peaks of Trp and one (X1) of the unidentified compounds produced from IPA, when dissolved, have emperically known to overlap each other. Therefore, it is essential to develop a method for the separation of Trp from X1 in order to study Trp biosynthesis from IPA. In the present paper, a newly established method for the separation of Trp from X 1 and the simultaneous quantitative determination of Trp by HPLC was studied.

\section{Materials and Methods}

\section{Apparatus}

A liquid chromatography pump (CCPM-II), variable wavelength ultraviolet detector (UV8020), column oven (CO-8020), degasser (SD8022) and autosampler (AS-8020) were obtained from Tosoh (Tokyo, Japan); the data analyser (Chromatopac, C-R $3 \mathrm{~A}$ ) was from Shimadzu (Kyoto, Japan) and the LiChrospher $100 \mathrm{RP}-18$ column (250 $\times 4 \mathrm{~mm}$ I.D.) of $5 \mu \mathrm{m}$ particle size was from Kanto Chemical (Tokyo, Japan) under the licence of E. Merck (Darmstadt, Germany).

\section{Chemicals}

L-Tryptophan was purchased from Wako Pure Chemical Industries (Osaka, Japan); IPA from Sigma (St. Louis, Mo, USA) and sulfosalicylic acid (SSA) from Nacalai Tesque (Kyoto, Japan). Ultra pure water made with Milli-Q Labo (Nihon Millipore Kogyo, Tokyo, Japan) was used to prepare the mobile phases and other solutions.

\section{Sample preparation}

Indole-3-pyruvic acid was dissolved in $25 \%$ ethanol. One- $\mathrm{m} l$ portion of $20 \mathrm{mM}$ IPA solution was added in $19 \mathrm{ml}$ MB9 buffer solution ${ }^{6)}$ and incubated it at $39^{\circ} \mathrm{C}$ for $14 \mathrm{~h}$ in $30 \mathrm{ml}$ Ehrlenmeyer flask. Samples were collected after $1,2,3,4,5,6,7$ and $14 \mathrm{~h}$ interval, mixed with an equal volume of $4 \%(\mathrm{w} / \mathrm{v}) \mathrm{SSA}$ and filtered through a $0.45 \mu \mathrm{m}$ membrane filter (Toyo Roshi Kaisha, Tokyo, Japan) before HPLC operation. Portions $(5 \mu l)$ of the filtrate were directly injected on to the HPLC system.

\section{Chromatography}

The mobile phase used for isocratic elution was methanol : $50 \mathrm{mM}$ sodium acetate buffer $(\mathrm{pH} 4.2)(20: 80, \mathrm{v} / \mathrm{v})$ and the $\mathrm{pH}$ was adjusted to 4.2 by $50 \mathrm{mM}$ acetic acid. Before use, the mobile phase was filtered with a membrane filter (HV $0.45 \mu \mathrm{m}$, Nihon Millipore Kogyo, Tokyo, Japan). The flow rate was $1.0 \mathrm{ml} / \mathrm{min}$; column temperature, $40^{\circ} \mathrm{C}$; monitoring wavelength at $280 \mathrm{~nm}$ with a UV absorbance detector ; column, LiChrospher 100 RP-18 (250×4 mm I.D.) of $5 \mu \mathrm{m}$ particle size.

\section{Results and Discussion}

In the present method, interference from compounds other than UV-absorbing substances such as aromatics could be easily avoided by the choice of a suitable monitoring wavelength $(280 \mathrm{~nm})$. The methanol concentration and $\mathrm{pH}$ value of the mobile phase influenced the retention time of the peaks of Trp and the unidentified compound (X 1 ) produced from IPA. In the present experiment, the methanol content and $\mathrm{pH}$ of the mobile phase were changed from 60 to $0 \%$ and from 3.6 to 5.6 , respectively. As a result, when methanol : 50 mM sodium acetate buffer ( $\mathrm{pH} 4.2)(20: 80, \mathrm{v} / \mathrm{v})$ was used, the peaks of Trp and the $\mathrm{X} 1$ were efficiently separated within 7 min (Fig. 1). This method can also separate Trp from its related 10 compounds reported by Mohammed et $a l^{5}{ }^{5}$, but the disadvantages of this method are that the retention time and minimum detectable limit were longer and lower, respectively, than those of the previously reported $\operatorname{method}^{5)}$. With the increasing methanol percentage and $\mathrm{pH}$ of the mobile phase, retention times of Trp and X 1 shortened and overlapped each other.

A linear relationship was obtained between the peak-heights and the different 


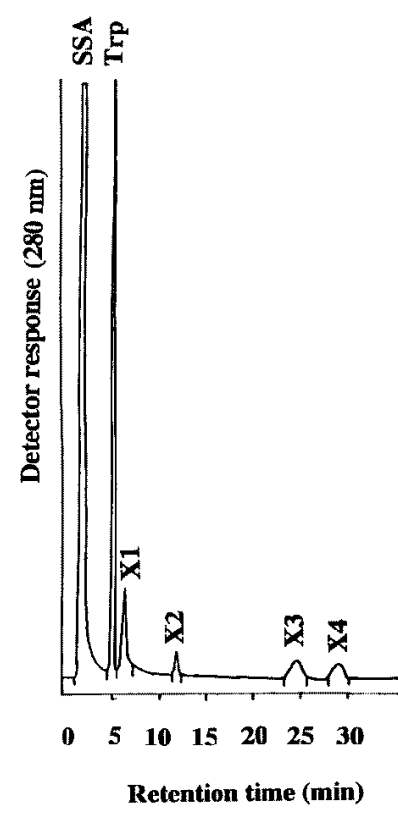

Fig. 1. Chromatogram of Trp (1 mM standard solution) mixed with equal volume of $1 \mathrm{mM}$ IPA after $2 \mathrm{~h}$ incubation in MB 9 buffer solution at $39^{\circ} \mathrm{C}$ and then deproteinized.

Mobile phase: methanol: $50 \mathrm{mM}$ sodium acetate buffer ( $\mathrm{pH} 4.2)(20: 80, \mathrm{v} / \mathrm{v})$.

Abbreviations: $\mathrm{SSA}=$ sulfosalicylic acid, IPA= indolepyruvic acid, Trp=tryptophan, $X 1=$ unidentified peak $1, X_{2}=$ unidentified peak $2, X_{3}=$ unidentified peak $3, \mathrm{X} 4=$ unidentified peak 4 .

concentrations of standard compound (Trp), and thus the concentration of Trp in the sample which contains $X 1$ and other related compounds can easily be calculated from their peak height. The minimum detectable limit of Trp was $40 \mathrm{pmol}$ and the correlation coefficient between peak height and concentration was 0.99999 .

The peak purity was confirmed by comparing the peak-height ratio of Trp, added in IPA solution at different wavelengths $(270 / 280 \mathrm{~nm})$ according to the report of Lefeng et al. ${ }^{4)}$. Different concentrations of Trp were added in IPA solution and the analytical recovery was calculated by comparing the concentration of Trp found in the mixture (Trp and IPA) with

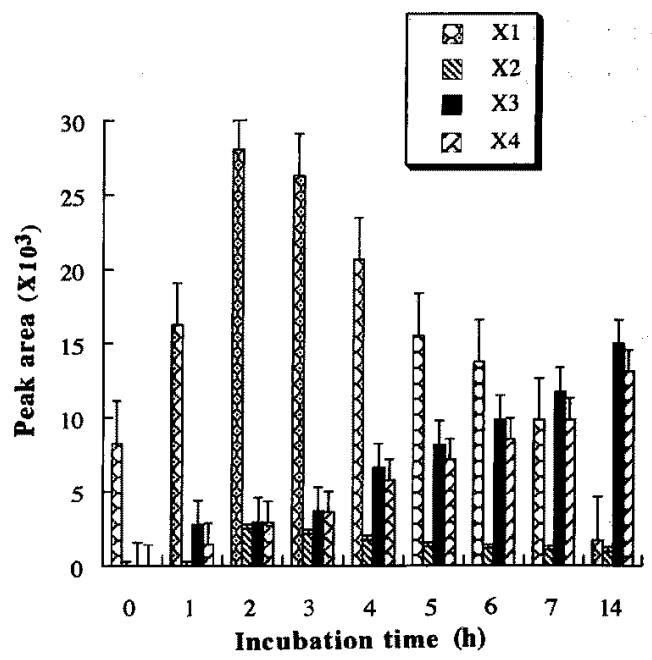

Fig. 2. Conversion of IPA in MB9 buffer solution to unidentified compounds $(X 1 \sim \mathrm{X} 4)$ during incubation at $39^{\circ} \mathrm{C}$ for $14 \mathrm{~h}$.

$\mathrm{X} 1$ =unidentified peak $1, \mathrm{X} 2=$ unidentified peak 2 , X $3=$ unidentified peak 3, X $4=$ unidentified peak 4 .

the standard concentration added in it. The recovery of Trp of the sample containing $\mathrm{X} 1$ was more than $96 \%$. Precision is expressed as the coefficient of variation and the accuracy as the bias. The coefficient of variation and bias range for four different concentrations of Trp added in IPA solution were varied between 0.19 to $3.35 \%$ and 0.13 to $3.84 \%$, respectively. The observed concentrations were in good agreement with the actual concentrations.

This method was applied to investigate the tendency of conversion of IPA to some uniden. tified compounds in MB9 buffer solution after incubation at $39^{\circ} \mathrm{C}$ for $14 \mathrm{~h}$. When $1 \mathrm{mM}$ of IPA was incubated in MB9 buffer solution at $39^{\circ} \mathrm{C}$ for $14 \mathrm{~h}$, four unknown peaks X 1, X 2, X 3 and $\mathrm{X} 4$ appeared, and peaks of $\mathrm{X} 3$ and $\mathrm{X} 4$ seemed to overlap with unknown compounds. Before incubation, only a small peak of X 1 was found on the chromatogram and after $1 \mathrm{~h}$ incubation, small peaks of X 3 and X 4 appeared. A small peak of X 2 appeared after $2 \mathrm{~h}$ incubation, but then it decreased gradually. The highest peak of $\mathrm{X} 1$ was found after $2 \mathrm{~h}$ incubation and then 
the peaks of $\mathrm{X} 1$ and $\mathrm{X} 2$ gradually decreased, and $X 3$ and $X 4$ gradually increased with the incubation time (Fig. 2).

We have tried to identify the four unknown peaks. Among them, the peak of $\mathrm{X} 2$ overlapped with the peak of indolelactic acid, X3 with indoleacetic acid and $X_{4}$ with indolealdehyde. X1, however, could not be identified as IPA itself, because IPA seemed not to dissolve so quickly as to be detected as a peak in HPLC, even though the IPA solution in 99.5\% ethanol was injected onto HPLC immediately after dissolved. It is assumed that X 1 and $X 2$ are gradually converted to $X 3$ and $X 4$ with incubation time, though we could not identify each compound.

\section{Acknowledgements}

The present study was financially supported partly by research grants from Kaken Pharmaceutical Co. Ltd., Tokyo, Japan and Daiichi Seiyaku Co. Ltd., Tokyo, Japan. Nazimuddin Mohammed and Rokibul Islam Khan thank to the Ministry of Education, Science, Sports and Culture of Japan (Monbusho) for the award of research studentship from 1996.

\section{References}

1) Allison MJ, Robinson IM. Tryptophan biosynthesis from indole-3-acetic acid by anaerobic bacteria in rumen. Biochem. J., $102: 36-37$. 1967.

2) Allison MJ, Robinson IM, Baetz AL. Tryptophan biosynthesis from indole-3-acetic acid by anaerobic bacteria from the rumen. J. Bacteriol., 117 : 175-180. 1974.

3) Kristensen S. Ruminal biosynthesis of aromatic amino acids from arylacetic acids, glucose, shikimic acid and phenol. Br. J. Nutr, $31: 357-$ 365. 1974.

4) Lefeng Z, Yunlu Y, Ruiyu Y. Direct determination of phenylalanine in serum extracts of phenylketonuria patients by reversed phase high-performance liquid chromatography. J. Chromatogram., 282 : 333-339. 1983.

5) Mohammed N, Onodera R, Khan RI. A new determination method of tryptophan and its related compounds by high-performance liquid chromatography and its application to rumen fluid. Anim. Sci. Technol. (Jpn.), 69 : 1020-1028. 1998.

6) Onodera R, Henderson C. Growth factors of bacterial origin for the culture of the rumen oligotrich protozoon, Entodinium caudatum. J. Appl. Bacteriol., 48 : 125-134. 1980. 